\title{
Targeting Bad Apples or the Whole Barrel?
}

\author{
The Legal Entanglements between Targeted and \\ Comprehensive Logics in Counter-Proliferation \\ Sanctions
}

\author{
GRÉGOIRE MALLARD AND AUREL NIEDERBERGER
}

\subsection{Introduction}

Jurists and legal historians have increasingly come to the realization that the story of their discipline is not, in fact, that of the gradual diffusion of Western concepts to the rest of the world. The emergence of new norms of global governance and the history of international law more generally are made up of multiple stories that have no single point of departure. ${ }^{1}$ The history of legal concepts, imaginaries and fields of practice is full of examples of such 'legal entanglements' between various systems of law, located at different scales, and generated according to different temporalities and historicities. ${ }^{2}$ The new historiography on colonialism and empires, for instance, has insisted on the two-way transport of legal concepts and practices and the plurality of legal orders that were constituted over time during the Spanish, British, French and even German empires. ${ }^{3}$ In many cases, scholars of colonial law have demonstrated that

This chapter is directly based on a project headed by Grégoire Mallard that received funding from the European Research Council under the European Union's Horizon 2020 research and innovation program (Grant Agreement PROSANCT, 'Bombs, Banks and Sanctions', Project 716216). The authors thank all the interviewees who participated in the research.

1 T. Duve, 'Entanglements in Legal History. Introductory Remarks', in T. Duve, Entanglements in Legal History: Conceptual Approaches (Max Planck Institute for European Legal History, 2014), pp. 3-25.

2 B. S. Chimni, International Law and World Order: A Critique of Contemporary Approaches (Cambridge University Press, 2017).

3 L. Benton, Law and Colonial Cultures: Legal Regimes in World History, 1400-1900 (Cambridge University Press, 2001); G. Steinmetz, The Devil's Handwriting: Precoloniality and the German Colonial State in Qingdao, Samoa, and Southwest Africa (University of Chicago Press, 2008); Duve, Entanglements in Legal History; J. Go, 'Global 
the colonizers' rule was far from being the sole source of authority and legitimacy in disputes between colonizers and colonial subjects. ${ }^{4}$ The resulting 'legal entanglements' may have looked contradictory in principle but were effective in practice. ${ }^{5}$

Similarly, political scientists have looked at the co-constitution of normative and/or rules-based regimes, which has grown increasingly more complex through practices of interlinkages. Experts often push the boundaries of technical fields of governance by claiming jurisdiction over the regulation of innovations in adjacent fields. Such practices promote an ever tighter entanglement between expert knowledge and policy domains, leading to either conflict, cooperation or free-riding by transnational policy networks, private companies and states. ${ }^{6}$ Political sociologists and socio-legal scholars have also recently paid attention to the circulation of various kinds of capital (economic, cultural, political or even colonial) and their transmission across entangled national and international regulatory fields. These scholars conclude that the distribution of such forms of capital does not follow a purely national logic, such that we need a transnational perspective on the workings of the state in the age of globalization. ${ }^{7}$

Although these various disciplines differ in methods and findings, we find, across fields, a number of scholars who seek to explain the evolution of complex forms of transnational legal rules as 'legal entanglements'. These scholars converge on some epistemic principles. They hold that history originates from many parts of the world; that asymmetries of

Fields and Imperial Forms: Field Theory and the British and American Empires' (2008) 26 Sociological Theory 201-29; G. Mallard, Gift Exchange: The Transnational History of a Political Idea (Cambridge University Press, 2019).

4 S. E. Merry, 'Legal Pluralism' (1988) 22 Law \& Society Review 869-96; see also S. E. Merry, Human Rights and Gender Violence: Translating International Law into Local Justice (University of Chicago Press, 2009).

${ }^{5}$ Colonial legal entanglements were not tightly tied together, and the multiple actors who circulated from one imperial order to another well tolerated multiplicity and contradiction in the interpretation of plural legal orders (see Benton, Law and Colonial Cultures).

6 S. C. Hofmann, 'Overlapping Institutions in the Realm of International Security: The Case of NATO and ESDP' (2009) 7 Perspectives on Politics 45-52; K. J. Alter and K. Raustiala, 'The Rise of International Regime Complexity' (2018) 14 Annual Review of Law and Social Science 329-49.

7 Y. Dezalay and B. Garth, The Internationalization of Palace Wars: Lawyers, Economists and the Struggle to Transform Latin American States (Chicago University Press, 2002); Y. Dezalay and B. Garth, Asian Legal Revivals: Lawyers in the Shadow of Empire (Chicago University Press, 2010); Steinmetz, The Devil's Handwriting; Go, 'Global Fields and Imperial Forms'; Mallard, Gift Exchange. 
power are inscribed in norms but that it is mostly in practice where power actually manifests itself - most often, through practices of knowing, classifying and reifying certain visions of the world. ${ }^{8}$ They also tend to agree that although some hidden path dependency may well explain the overall direction of history, the continued existence of normative contradictions within any given 'regime complex'9 leaves room for contingencies and even sudden reversals. Importantly, scholars who use the notion of 'legal entanglement' accept that normative contradictions do not necessarily threaten the working and stability of a transnational legal order. ${ }^{10}$ This position departs from the traditional rationalistic view that a normative system can only be stable if it is based on clear, selfreinforcing and non-contradictory principles, such that one can derive from it rules of conduct and agreed-upon punishments in case of violations. The notion of 'legal entanglement' therefore introduces a 'postmodern' perspective ${ }^{11}$ to modernity's rationalist project of building universal rules beyond the nation state based on clear and quasiconstitutional foundations.

In this chapter, we adopt a similar perspective on 'legal entanglements' to explain contemporary dynamics in transnational legal orderings in the field of security. In particular, we want to explain the normative order by which states adopt international sanctions against individuals and/or states which have threatened international security and/or violated agreed-upon rules. We start from the assumption that sanctions are better thought of as bodies of norms and practices, also known as 'sanctions regimes.' ${ }^{12}$ These sanctions regimes have long been elaborated at the intersection of various bodies of law, both at the domestic and international levels, which define principles related to the responsibility of states and/or norms ensuring the protection of human rights. For

${ }^{8}$ M. Foucault, Discipline and Punish: The Birth of the Prison (Vintage, 1995).

9 Alter and Raustiala, 'The Rise of International Regime Complexity'.

10 T. C. Halliday and G. Shaffer, Transnational Legal Orders (Cambridge University Press, 2015); D. Halberstam and E. Stein, 'The United Nations, the European Union, and the King of Sweden: Economic Sanctions and Individual Rights in a Plural World Order' (2009) 46 Common Market Law Review 13-72.

${ }^{11}$ M. Koskenniemi and P. Leino, 'Fragmentation of International Law? Postmodern Anxieties' (2002) 15 Leiden Journal of International Law 553-79.

12 T. J. Biersteker, S. E. Eckert and M. Tourinho, 'Thinking about United Nations Targeted Sanctions', in T. J. Biersteker, S. E. Eckert and M. Tourinho (eds), Targeted Sanctions: The Impacts and Effectiveness of United Nations Action (Cambridge University Press, 2016), pp. 11-37. 
instance, the notion that innocent civilians should not suffer from the application of sanctions was translated in the United Nations Security Council (UNSC) sanctions regimes that were once 'comprehensive' and showed little respect to the human rights of populations in sanctioned areas, and that have become more targeted - or, in other words, 'smarter. ${ }^{13}$ This 'miniaturization' of UN sanctions began with various sanctions against conflict actors in Africa in the late 1990s and early 2000s, and it was further developed with the well-known sanctions regimes against Iran and North Korea, at least in their earlier stages in the 2000s. These processes occurred according to different temporalities and scales depending on where they were located.

This chapter argues that, on the one hand, the developments that have affected the sanctions regime have strengthened the normative coherence of the UN system of norms and rules, giving it more legitimacy and unity. The new UNSC sanctions regime was indeed greeted as a reconciliation of the UNSC's main responsibility to safeguard international peace and security with better respect for other pillars of international law and the UN, namely human rights, which include the right to access vital goods such as food or medical care. ${ }^{14}$ On the other hand, it remains to be seen whether new contradictions have not also spurred from some of the latest developments in the broader 'sanctions regime', which not only includes the UNSC sanctions but also multiple domestic sanctions regimes, in particular in the United States and Europe. In contrast to the story of a clear paradigmatic shift characterized by the emergence of a new 'targeted sanctions' paradigm, relegating to the dustbin of history all previous forms of comprehensive sanctions that clashed with other UN norms, we explain how, particularly in counter-proliferation sanctions, contradictions persisted in the legal entanglements between targeted and comprehensive logics and in overlapping multilateral and domestic legal sources of sanctions. We further explain why the presence of such contradictions in counter-proliferation regimes has gone largely unnoticed by 'targeted sanctions' designers and advocates who do not use the notion of 'legal entanglement'. ${ }^{15}$

13 D. W. Drezner, 'How Smart Are Smart Sanctions?' (2003) 5 International Studies Review 107-10.

14 E.g., Article 25 of the Universal Declaration of Human Rights.

15 J. J. Lew and R. Nephew, 'The Use and Misuse of Economic Statecraft: How Washington Is Abusing Its Financial Might' Foreign Affairs (November/December 2018), 139-49. 
In this chapter, we will thus show the heuristic power of the notion of 'legal entanglement' when applied to the evolution of global sanctions regimes in the last thirty years. To demonstrate how targeted sanctions regimes in the field of counter-proliferation are best analysed as 'legal entanglements' between targeted and comprehensive logics, as well as between multilateral and unilateral regimes, the chapter proceeds in three parts. In Section 9.2, we show how a discourse on the 'targetedness' of sanctions was promoted by sanctions entrepreneurs, policy experts and international governmental and non-governmental organizations in the context of the 'War on Terror' during which sanctions increasingly targeted specific individuals listed by states for their association with non-state networks of terrorists, namely Al Qaeda, the Taliban and later ISIS. In Section 9.3, we show how the multilateral machinery that was created in the context of counter-terrorism initiatives, especially under the aegis of the UNSC, extended its reach to the field of counterproliferation, when specific sanctions committees modelled after the $\mathrm{Al}$ Qaeda Sanctions Committee were created in the UNSC to monitor UN member states' compliance with new UNSC Resolutions (UNSCRs) that targeted the Democratic People's Republic of Korea (DPRK) and Iran's sanctioned nuclear activities. In Section 9.4, we show how, during the early 2010s, the targeted sanctions that the UNSC imposed on the DPRK and Iran were 'comprehensivized'. This process of comprehensivization, we show, followed different pathways: the comprehensivization of UNSC sanctions occurred either directly at the level of the UNSC (as in the case of the DPRK), or indirectly (as in the case of Iran), because of the entanglement between UNSC sanctions with the comprehensive logic of domestic sanctions adopted in a unilateral fashion by the United States and the European Union. This was the case regardless of claims by the USA, and especially by the EU, that their 'multilateral restrictive measures' (as sanctions are called in EU parlance) did not amount to comprehensive measures.

Our analysis shows that the legal entanglements between targeted and comprehensive logics that traverse the global sanctions regimes rest on a few core mechanisms. These mechanisms include the assertion of judicial authority by US regulators over the world's financial transactions denominated in US dollars; the use of instruments that designated central actors within designated jurisdictions (in particular, the central banks of sanctioned states); and the ambiguity of the concept of 'risk' held by global financial actors, which allowed financial institutions to adopt a 'zero-risk' approach when it came to the implementation of financial 
sanctions. ${ }^{16}$ The ambiguity of this concept of risk, which circulated through a network of cross-references across regulatory documents, ${ }^{17}$ led financial institutions to massively cut their operations in the targeted economy while remaining, on the face of it, within the bounds of the targeted logic of 'risk-based approaches'. We conclude by highlighting key normative reflections that derive from the realization that such entanglements between targeted and comprehensive logics are central to the operation of counter-proliferation sanctions.

\subsection{The Creation of the UNSC Counter-Terrorist Sanctions Regime and Its Extension to the Field of Counter-Proliferation: A Case of Isomorphism?}

The application of sanctions is not new, as states have long agreed upon historically specific appropriate responses against threats to peace and security as well as violations of international norms and rules. ${ }^{18}$ However, the move towards targetedness appears to be a more recent phenomenon, spurred by the UNSC's efforts to respond to recent crises, taking advantage of equally recent phenomena, such as the new information technologies that facilitate the identification of individual targets, ${ }^{19}$ the acceptability of designating non-state actors as subjects of international law and the desire of the international community to protect innocent civilians during responses against state and non-state perpetrators.

The global push towards more coherence in the UN system of norms that affected the design and monitoring of sanctions at the UNSC came with the realization that, after the Cold War, comprehensive sanctions

16 G. Mallard, 'Governing Proliferation Finance: Multilateralism, Transgovernmentalism and Hegemony in the Case of Sanctions against Iran', in E. Brousseau, J.-M. Glachant and J. Sgard (eds), Oxford Handbook of Institutions of International Economic Governance and Market Regulation (Oxford University Press, 2019).

17 A. Riles, 'Models and Documents: Artifacts of International Legal Knowledge' (1999) 48 International and Comparative Law Quarterly 805-25.

${ }^{18}$ M. Finnemore, The Purpose of Intervention: Changing Beliefs about the Use of Force (Cornell University Press, 2004).

19 M. de Goede and G. Sullivan, 'Introduction: The Politics of the List' (2016) 34 Environment and Planning D: Society and Space 3-13; for a comprehensive review of the legal and technical developments in the UNSC counter-terrorism sanction regime, see G. Sullivan. The Law of the List: UN Counterterrorism Sanctions and the Politics of Global Security Law (Cambridge University Press, 2020). 
proved too devastating in a less divided world. From 1945 until 1989, the world was divided into trading blocs; thus, a country that was excluded by one bloc could still trade with the other bloc. Therefore, 'sanctions' in the sense of trading restrictions applied by the West for instance may have been comprehensive in design, but never fully sealed off a country. Furthermore, the UNSC sanctions that were adopted in 1966 against Rhodesia, and in 1977 against South Africa, were limited to arms embargoes. This changed with the end of the Cold War. In 1990, the UNSC unanimously imposed comprehensive sanctions on Iraq after Saddam Hussein's invasion of Kuwait. While these sanctions were modelled on the initiative of the West, in particular the USA, they were backed by universal condemnation of the Iraqi act of aggression. These sanctions initially consisted of an embargo against all Iraqi imports and exports and were to be applied by all UN member states. Their effects were drastic and counterproductive: even though exemptions on food and medical supplies were gradually introduced, the impact on the civilian population was devastating, while hardly hurting - or, by some accounts, even strengthening - Saddam Hussein's regime. ${ }^{20}$ This paradigmatic case of comprehensive sanctions convinced the international community to move towards a targeted design of sanctions to avoid hurting civilians in sanctioned territories. ${ }^{21}$

In the following years (i.e. the late 1990s and early 2000s), a 'transnational policy network' of diplomats, national politicians and academics promoted these targeted sanctions, consisting of tools such as assets freezes, travel bans, sectoral economic restrictions and arms embargoes. ${ }^{22}$ These targeted sanctions became the only type of sanctions imposed by the UNSC since, with early applications responding to internal armed

20 D. Cortright and G. A. Lopez, The Sanctions Decade: Assessing UN Strategies in the 1990s (Lynne Rienner, 2000); J. Gordon. Invisible War: The United States and the Iraq Sanctions (Harvard University Press, 2012).

${ }^{21}$ M. W. Reisman and D. L. Stevick, 'The Applicability of International Law Standards to United Nations Economic Sanctions Programmes' (1998) 9 European Journal of International Law 86-141.

22 T. J. Biersteker, 'Scholarly Participation in Transnational Policy Networks: The Case of Targeted Sanctions', in M. E. Bertucci and A. F. Lowenthal (eds), Narrowing the Gap: Scholars, Policy-Makers and International Affairs (Johns Hopkins University Press, 2014), pp. 137-54. 
conflicts in Angola, Sierra Leone, and Liberia in the late 1990s and early 2000 s. $^{23}$ Since then, as a sign of the normative appeal of targeted sanctions, human rights organizations - staunch critics of the comprehensive sanctions against Iraq - have repeatedly called for the imposition of targeted sanctions in the context of various civil wars. ${ }^{24}$ Consequently, academic literature on sanctions has usually spoken of a clear break between the comprehensive Iraq sanctions and the post-Iraq era of 'targeted sanctions', ${ }^{25}$ whose coherence with the broader system of UN norms is emphasized by many. ${ }^{26}$

In the late 1990s and early 2000s, a series of large-scale terrorist attacks - most prominently $9 / 11$ - pushed states to confront transnational non-state groups as significant threats to their security. The ensuing War on Terror involved UN targeted sanctions that were similar in their formal setup to the peacebuilding sanctions put in place in response to African civil wars, but came with longer lists of targeted individuals and entities. As a further difference, while early peacebuilding sanctions included sectoral trade embargoes (such as diamonds), the targets of counter-terrorism sanctions were too amorphous for such measures. Instead, these sanctions regimes relied chiefly on financial measures and travel bans. During the 2000s, under the stimulus of the UNSC, the financial sector thus became heavily mobilized in the quest for more efficiency and more targetedness in the fight against individual terrorists linked to $\mathrm{Al}$ Qaeda. ${ }^{27}$ The range of measures imposed on those individuals who were added to the list of identified terrorists were (and continue to be) forceful, including asset freezes and the systematic screening of all cross-border transactions. Immediately after $9 / 11$, the United States - and then the UNSC - asked the financial sector to help them with implementing this targeted logic with measures to counter the

23 D. Cortright and G. A. Lopez, 'Introduction: Assessing Smart Sanctions: Lessons from the 1990s', in D. Cortright and G. A. Lopez (eds), Smart Sanctions: Targeting Economic Statecraft (Rowman \& Littlefield Publishers, 2002), pp. 1-22.

24 A. Niederberger, 'Expert Networks and the Emergence of Practice in UN Arms Embargo Monitoring', Paper presented at EISA PEC 2019 (2019).

${ }^{25}$ Biersteker, Eckert and Tourinho, 'Thinking about United Nations Targeted Sanctions'; E. Solingen, Sanctions, Statecraft, and Nuclear Proliferation (Cambridge University Press, 2012).

${ }^{26}$ R. Nephew, The Art of Sanctions: A View from the Field (Columbia University Press, 2017).

27 J. Zarate, Treasury's War: The Unleashing of a New Era of Financial Warfare (Hachette, 2013). 
financing of terrorism (CFT). This request inspired new conceptions, practices and technologies. ${ }^{28}$ For instance, before $9 / 11$, banks conceived of financial fraud as a problem of organized crime and corruption and used almost no digital technology to detect such fraud among their clients; after 9/11, however, financial watchdogs and software companies offered their techniques as weapons in the War on Terror, enabling identification and blocking of specific transactions, as well as automatic freezing of the money held in suspicious accounts. ${ }^{29}$ It was, therefore, as part of the War on Terror that targeted financial measures were devised and implemented on a large scale. ${ }^{30}$

Thus, after targeted sanctions were initially designed as a response to the costly impact of comprehensive sanctions against Iraq (as explained earlier in this section), the War on Terror played an important role in further developing and promoting this tool. Throughout the years, the UNSC made a consistent effort to keep the sanctions directed at the right targets and not to harm innocent civilians by constantly improving the technical characteristics of its mode of designation. For instance, the UNSC sought to specify the identities of targeted terrorists with enough detail to prevent banks from unintentionally applying the penalties against 'false positives' (i.e. entities or individuals who are mistakenly identified as sanctioned actors because their names coincide with names on the sanctions list). After international pressure and legal conflicts in European countries, the UNSC also created the office of the 'Ombudsperson' which gives listed individuals the possibility to appeal for delisting by demonstrating that they no longer meet the listing criteria. ${ }^{31}$ The 'politics of lists ${ }^{32}$ and financial surveillance thus became intrinsic parts of the logic of targetedness that was developed in the new War on Terror, first within the Bush administration and later by the international community at the UNSC level.

28 See Sullivan, The Law of the List.

29 G. Mallard and A. Hanson, 'Embedded Extra-Territoriality: US Judicial Litigation and the Global Banking Surveillance of Digital Money Flows', in C. Beaucillon (ed.), Research Handbook on Unilateral and Extraterritorial Sanctions (Edward Elgar, 2021), pp. 269-86.

30 M. S. Navias, 'Finance Warfare as a Response to International Terrorism' (2002) 73 The Political Quarterly 57-79.

31 M. de Goede and G. Sullivan, 'Between Law and the Exception: The UN 1267 Ombudsperson as a Hybrid Model of Legal Expertise' (2013) 26 Leiden Journal of International Law 833-54.

32 De Goede and Sullivan, 'Introduction: The Politics of the List'. 
New actors entered the domain of CFT, as counter-terrorism sanctions incited new cooperation (or intensified existing cooperation) between member states' bureaucracies (notably intelligence agencies and treasury departments), private companies (especially airline companies and global banks) and international organizations. ${ }^{33}$ Prominent among the last of these was the Financial Action Task Force (FATF): an international organization of like-minded states that was established at a G7 summit in 1989 with the mandate to 'examine and develop measures to combat money laundering. ${ }^{34}$ In October 2001 - in the aftermath of 9/11 - the FATF mandate was then extended from anti-money laundering (AML) to CFT, leading to FATF's entry into the field of international security; as we show in Section 9.3, the mandate was later expanded to include counter-proliferation finance (CPF). It wasn't so much the FATF staff which lobbied to be entrusted with these security-related tasks, as at that time it possessed little expertise and credentials in international security. However, according to policy insiders we interviewed, the member states deemed it preferable to entrust a small organization, largely dependent upon member state intel, with the tasks of improving CFT strategies and helping the UNSC enrol the banking sector in its fight against terrorists.

The FATF worked hard to empower member states with 'better' legislation through the diffusion of best practices or model law in AML, CFT or CPF fields, as well as to provide private financial institutions with knowledge about typical money-laundering and terrorismfinancing schemes. ${ }^{35}$ As such, the UNSC and the FATF have cooperated in the elaboration of a logic of targetedness in the design of counterterrorism sanctions. In parallel, in the UNSCRs against Iran (for instance, in UNSCR 1803), ${ }^{36}$ the UNSC started to make explicit references to and praise the work of the FATF, and called on all governments to push legislation addressing financial sector reform that would enable banks

33 See Mallard, 'Governing Proliferation Finance'.

34 The FATF is an organization with strong expert authority and little legal authority as it only counts thirty-seven state members (as of 2020, up from thirty-four in 2008) and two regional organizations (the European Commission and the Gulf Co-operation Council) among its members. Monitoring and enforcement mechanisms are restricted to its member states, on the basis of the yearly questionnaire that FATF member states conduct as self-evaluations of their implementation of the FATF's core principles (namely its forty general recommendations and its nine recommendations to counter the financing of terrorism), and on the basis of periodic mutual evaluations, see J. Johnson, 'Is the Global Financial System AML/CFT Prepared?' (2008) 15 Journal of Financial Crime 7-21.

35 FATF, 'Typologies Report on Proliferation Financing' (18 June 2008).

36 UNSC Res 1803 (3 March 2008) UN Doc S/RES/1803. 
and other private financial operators to fully cooperate with the creation of the new system of targeted sanctions. All international organizations with a stake in the global sanctions regimes have thus seemed to converge towards the same goals, well in line with broader UN norms.

When applied against 'pariah' states designated by the Bush administration in 2003 - in this case, Iran and the DPRK - the same logic of targetedness that shaped the design of counter-terrorism sanctions meant that new counter-proliferation sanctions would also avoid hurting the civilian populations who were not responsible for the undeclared nuclear programmes. ${ }^{37}$ After Iran's file was sent from the International Atomic Energy Agency (IAEA) Board of Governors to the UNSC in 2006, as well as after the UNSC passed sanctions against the DPRK in the wake of its first nuclear test in 2006, the UNSC adopted successive rounds of sanctions against both countries that were targeted rather than comprehensive in scope, and discriminatory rather than non-discriminatory in nature. $^{38}$ Their targeted nature was exemplified by the specific designation of companies and individuals allegedly associated with Iran's or the DPRK's nuclear programmes. These entities were systematically listed in the appendices of each of the UNSCRs targeting the two countries just like the UNSC Al Qaeda sanctions listed scores of names associated with the terrorist network.

In the case of Iran, for instance, UNSCR 1737, passed in December 2006, banned the supply of specific goods (e.g. nuclear-related material) to Iran and froze the assets of specific individuals and companies associated with Iran's hidden centrifuge programme. ${ }^{39}$ Similarly, UNSCR 1929, passed in June 2010, only called upon states to exercise vigilance over the transactions of the assets of entities associated with the procurement of illicit goods, such as members of the Iranian Revolutionary Guard Corps listed in its Annex II. ${ }^{40}$ The same logic of targetedness characterized UN sanctions against the DPRK, at least until the end of the Obama presidency, whose focus was on negotiations with Iran rather than the DPRK. Therefore, the UN counter-proliferation sanctions were indeed initially devised as targeted sanctions.

37 G. Mallard, 'Antagonistic Recursivities and Successive Cover-Ups: The Case of Private Nuclear Proliferation' (2018) 69 The British Journal of Sociology 1007-30.

38 Zarate, Treasury's War.

39 UNSC Res 1737 (23 December 2006) UN Doc S/RES/1737.

40 UNSC Res 1929 (9 June 2010) UN Doc S/RES/1929. 
The institutionalization of the logic of targetedness in the domain of counter-proliferation was facilitated by the UNSC's cooperation with other international organizations and by intertextuality and crossreferencing across various actors. As with the counter-terrorism sanctions, the UNSC worked in tandem with other organizations, again notably with the FATF. ${ }^{41}$

The UNSC passed UNSCR 1803 in 2008, which commended the guidelines issued by the FATF that same year with regard to the detection of suspicious activities in proliferation finance. ${ }^{42}$ UNSCR 1803 'called upon' all states to exercise 'vigilance' regarding activities of financial institutions in their territory with banks domiciled in Iran 'in order to avoid such financial support contributing to the proliferation sensitive nuclear activities' (para. 10), and to report to the UNSC's Sanctions Committee on Iran the steps undertaken to this end.

The UNSC and the FATF thus incentivized states and banks to work towards a decentralized and autonomously targeting financial system, in which private and public financial institutions are individually responsible for establishing mechanisms to ensure compliance with sanctions regimes. In principle, these institutions remained committed to the same logic of targetedness: both FATF documents and UNSCRs promoted specific measures (like 'enhanced due diligence' protocols) that global banks could adopt in order to conduct proper calculations of the risk of certain activities of their clients being related to Iran's sanctioned nuclear activities. Banks should only prevent those activities if the risk was substantial. As described in interviews we conducted with US sanctions specialists, such intertextuality and cross-referencing were strengthened due to the fact that the same experts (largely Western experts, in particular those working on sanctions in the US State and Treasury

41 The first important FATF report on counter-proliferation financing was published in 2008, although according to its website, it was only in 2012 that combating proliferation finance was added to the FATF's mandate (www.fatf-gafi.org/about/whatwedo/).

42 In the context of the DPRK, it was only in 2013 that UNSCR 2094 referred to the FATF, when it 'welcomed' the FATF's recommendation 7 and the interpretative note along with that recommendation, which was newly added to the list of FATF recommendation in 2012. The recommendation simply calls upon states to implement targeted sanctions in compliance with UNSCRs. As the UNSC 'urged' states to apply this recommendation (more precisely, the FATF's interpretive note on the recommendation), it did so only in the preamble of the UNSCR, that is, not as a binding Chapter VII measure. The UNSC reinforced this call three years later, in 2016, and now in the decision part of the resolution (UNSCR 2270 from 2016, para. 38), still referring, however, only to recommendation 7 and using the less binding expression to 'call upon' states. 
Departments) contributed to the activities of both institutions (the UNSC and FATF).

Still, some other trends in the sanctions against Iran and the DPRK force us to rethink the narrative of a clear break with the comprehensive logic of sanctions. Considering the increasing difficulties that countries under sanctions (like Iran or DPRK) meet when they have to respond to the humanitarian needs of their populations, ${ }^{43}$ does that mean that the paradigmatic shift towards targeted sanctions has been reverted? Or has that paradigmatic shift in fact never fully happened, as a comprehensive logic (or a process of comprehensivization) continued to be produced as a result of the entanglement between various sanctions regimes, some at the unilateral level, others at the multilateral level? As UNSC sanctions haven't operated in a vacuum since the turn to 'targeted sanctions', and as they have consistently been complemented by domestic sanctions unilaterally adopted by UNSC permanent member states (especially the P3 - the USA, the UK and France), has the UNSC relinquished its duty of ensuring the coherence of its actions vis-à-vis the broader UN normative system? These questions are especially urgent to ask since the legality and normative coherence of unilateral sanctions adopted by the P3 with other UN principles, such as the protection of human rights, has increasingly been the object of criticism, even from within the UN system, as illustrated for instance by the many reports published by the office of the UN Special Rapporteur on the Negative Impact of Unilateral Coercive Measures on the Enjoyment of Human Rights. ${ }^{44}$

\subsection{The Internal Dynamics Driving the Gradual Comprehensivization of Sanctions: The Role of Panels of Experts}

Some analysts may argue that counter-terrorism sanctions, and most notably the financial measures they entailed, buttressed the normative

${ }^{43}$ G. Mallard, F. Sabet and J. Sun, 'The Humanitarian Gap in the Global Sanctions Regime: Assessing Causes, Effects and Solutions' (2020) 26 Global Governance: A Review of Multilateralism and International Organizations 1-33.

44 OHCHR, 'Research-Based Progress Report of the Human Rights Council Advisory Committee Containing Recommendations on Mechanisms to Assess the Negative Impact of Unilateral Coercive Measures on the Enjoyment of Human Rights and to Promote Accountability' (10 February 2015) UN Doc A/HRC/28/74; OHCHR, 'Report on the Negative Impact of Unilateral Coercive Measures on the Enjoyment of Human Rights' (30 August 2018) UN Doc A/HRC/39/54. 
standard of hitting those responsible while avoiding costs for innocent civilians. ${ }^{45}$ However, we argue that those sanctions also entailed a redirection of intervention practices, new types of expertise, technologies and cooperative engagements that amounted to a loss of control in how UNSC sanctions were to be implemented by the private parties (global banks especially) in charge of blocking financial transactions on the basis of suspicion rather than a demonstrated relation to the nuclear programmes of Iran or North Korea. In this section, we want to show how the logic of targetedness that the UNSC and FATF inscribed in the regulation of counter-proliferation finance was gradually entangled with a logic of comprehensiveness.

The UNSC's innovative approach to targeted sanctions went well beyond the publicization of lists of names of suspected terrorists and nuclear proliferators, and the description of their financial practices, found in the documents voted upon by fifteen UNSC and thirty-seven FATF member states. The powerful states behind the edification of the new sanctions regimes called for implementation by all states and for cooperation by private actors around the world (such as global banks and airline companies), asking them to deeply reform their compliance systems in order to catch suspicious transactions. It is thus important to understand UN sanctions and FATF recommendations not simply as an attempt by the UNSC or FATF to reign in one specific actor (Al Qaeda and its individual affiliates, or the individual companies and persons related to the nuclear programmes of Iran and the DPRK), but as an attempt to govern states - all of them - and to convince them to reform their banking sectors so as to ensure that they can detect suspicious transactions and freeze the assets of terrorists and suspected nuclear proliferators in seconds, without hurting the rest of their population.

Here is, thus, a particular mélange of international and transnational logics inherent to targeted sanctions, as they target non-state actors through addressing state jurisdictions. States were furthermore not just asked to inhibit certain flows of finances, goods and people, but to change their domestic financial regulations more broadly. This focus on broader financial regulations was likely promoted by the FATF, as the FATF is less concerned with individual security threats such as those emanating from Al Qaeda, Iran or the DPRK, and more with systematic patterns and risks of abusing the financial system. These more systematic

${ }^{45}$ Zarate, Treasury's War. 
concerns were increasingly integrated into UNSC resolutions, asking all $\mathrm{UN}$ member states to change their domestic jurisdictions.

These demands contain the seed of a 'comprehensivization' of supposedly targeted sanctions, as banks worldwide were pushed by the UNSC and FATF (through the pressure these two international organizations placed on governments) to become part of a larger governance infrastructure, whose algorithms automatically hooked the compliance departments of global banks to the listing decisions of the UNSC and other entities. Even though the UNSC itself remained rather conservative with regards to listing individuals (its list of targeted terrorists containing about 350 individuals/entities), its regulations contributed to a dynamic of ever-growing lists and their almost automatic adoption by global banks: the targeting is supposed to become decentralized and automatized at a systematic level, a far cry from the few handpicked, high-profile targets of the early peacebuilding sanctions whose evolution remained heavily centralized in the hands of the UNSC.

The banking reforms adopted by the UNSC and FATF have led to the creation of a system of private 'algorithmic governance ${ }^{46}$ which led to eternally growing lists that were supposed to capture a fluid enemy. Given the fluidity of this non-state enemy, the asset-freezing measures could never be called 'comprehensive': soon, private companies such as WorldCheck proactively identified targets on their own and sold these listings to global banks. ${ }^{47}$ As many compliance officers working in the banking sector told us in the context of a large-scale interviewing campaign conducted between 2017 and 2019, once individuals are on a list sold by compliance software companies to banks, they will remain black-listed by some banks for the rest of their lives, even if their name is later removed from listings due to the decision of a court or the UNSC ombudsperson. The exclusion of individuals has also become maximalist because private companies have tended to pile up names from not only UNSC listings, but also all the domestic lists that states from all over the world publicize, rarely having the means of checking in which jurisdictions any given individual is listed and therefore just applying all lists globally.

${ }^{46}$ F. Pasquale, The Black Box Society (Harvard University Press, 2015); M. Ziewitz, 'Governing Algorithms: Myth, Mess, and Methods' (2016) 41 Science, Technology \& Human Values 3-16; S. U. Noble, Algorithms of Oppression: How Search Engines Reinforce Racism (New York University Press, 2018); C. Katzenbach and L. Ulbricht, 'Algorithmic Governance' (2019) 8 Internet Policy Review, https://doi.org/10.14763/2019 .4.1424.

${ }^{47}$ De Goede and Sullivan, 'Introduction: The Politics of the List'. 
The demands for domestic regulatory change that the UNSC made on behalf of international security concerns have had other important implications. Existing literature has analysed it as an indication of the UNSC becoming a 'global legislator'. ${ }^{48}$ Here, however, we want to point out a different implication, namely the creation of new institutions and monitoring mechanisms that would contribute to a network of crossreferencing reports and regulatory guidelines. As the UNSC set up new sanctions regimes, it instituted new Sanctions Committees, to which it appended specific Panels of Experts (PoEs), which participated in the expansion of lists of designated individuals and which changed the relationship between political negotiation and the rule by experts. PoEs are mandated to 'gather, examine and analyze information from States, relevant United Nations bodies and other interested parties regarding the implementation of the measures imposed in [the respective resolutions]' and to 'make recommendations on actions the Council, or the Committee or Member States, may consider to improve implementation of the measures' in their annual or biannual reports. ${ }^{49}$ PoEs are supposed to have the necessary independence from UN member states to scrutinize the national implementation of specific UNSCRs, like those targeting $\mathrm{Al}$ Qaeda, Iran or the DPRK.

It is necessary to point out that the setup of these PoEs has been very political, as the nationalities of their members mirror the five permanent members of the UNSC plus the composition of member states involved in the broader negotiation with, respectively, Iran and the DPRK. ${ }^{50}$ This political dimension of their work goes largely unacknowledged, even though some observers of the UN sanctions machinery acknowledge in interviews a divide between PoE members

${ }^{48}$ E. Rosand, 'The Security Council as Global Legislator: Ultra Vires or Ultra Innovative United Nations and the Law of War' (2004) 28 Fordham International Law Journal 542-90; K. L. Scheppele, 'The Migration of Anti-Constitutional Ideas: The Post-9/11 Globalization of Public Law and the International State of Emergency', in S. Choudhry (ed.), The Migration of Constitutional Ideas (Cambridge University Press, 2007), pp. 347-73; N. Krisch, 'International Law in Times of Hegemony: Unequal Power and the Shaping of the International Legal Order' (2005) 16 European Journal of International Law 369-408; N. Krisch, 'Decay of Consent: International Law in an Age of Global Public Goods' (2014) 108 American Journal of International Law 1-40.

49 UNSC Res 1874 (12 June 2009) UN Doc S/RES/1874, para. 26.

50 For Iran, each of the E3+3 (or, in the language of the UN, the P5+1) sends one expert; for the DPRK, each of the member states involved in the Six Party talks sends one expert, plus one further member. In addition, one panel member from a non-aligned country is added to both panels. 
who adopt a maximalist interpretation of the UNSCRs, which come closer to the views of the $\mathrm{P} 3$, and others who take a minimalist interpretation closer to the souverainism of Russia and China. It should be noted that, despite their formal independence, many PoE members hold a background in national ministries or agencies and sometime maintain close contacts with their country representatives in New York or even with their capital throughout the mandate, and interpret sanctions violations in accordance with their capital's view. ${ }^{51}$ As for PoE members from P3 countries, this also entails closer direct or indirect ties to other multilateral institutions which hold similar views, like the FATF, or with like-minded think tanks specialized in the monitoring of the global arms trade or illicit finance, like the Stockholm International Peace Research Institute or the International Crisis Group. In their daily practice as PoE members, they are entitled to escape the logic of pure diplomatic negotiation by checking information that they obtain through personal networks and then pushing for factual consensus on such sensitive issues as sanctions implementation, enforcement, and redress. ${ }^{52}$

In the field of CPF, PoEs and the FATF have reinforced each other, mutually 'enhanc[ing] their own position by linking up with bodies of norms produced by other, reputed institutions. ${ }^{53}$ In so doing, they elaborated and universally promoted a set of financial rules that originated in Western states and was diffused by the P3 to the rest of the world. To begin with, PoE reports - which are submitted to the UNSC and made public - regularly refer to FATF reports: for example, the section on financial sanctions in the first report of the DPRK PoE mostly just reprinted the heuristics on money laundering from a 2008 FATF report. Already in its first report on the DPRK sanctions, the PoE recommended that '[a]ll Member States should be encouraged to adopt and implement the non-proliferation and anti-money-laundering/combating the financing of terrorism guidelines published by FATF' (DPRK S/2010/571,

51 This accounts for the DPRK PoE and the Iran PoE (prior to the JCPOA), rather than the PoEs responsible for African regimes, see: A. Niederberger, 'Independent Experts with Political Mandates: "Role Distance" in the Production of Political Knowledge' (2020) 5(3) European Journal of International Security 350-71.

52 A. Niederberger, 'Investigative Ignorance in International Investigations: How United Nations Panels of Experts Create New Relations of Power by Seeking Information' (2018) 69 The British Journal of Sociology 984-1006; Niederberger, 'Independent Experts with Political Mandates'.

53 See Chapter 1. 
recommendation 15). ${ }^{54}$ We should assume that the term 'member states' refers to UN member states here (as it usually does in PoE reports), not to FATF member states, meaning that the PoE recommended that states adopt FATF guidelines even if they are not a member of the organization.

Another illustrative example concerns measures against front companies, which have frequently been used to circumvent sanctions: front companies have been repeatedly problematized in FATF reports, ${ }^{55}$ but remained largely ignored by UNSCRs, with the minor exception of a few designations of front companies in UNSCR 1803 on Iran. ${ }^{56}$ However, after the DPRK PoE recommended more systematic measures be forcefully undertaken against front companies (S/2015/131, recommendation B7), ${ }^{57}$ the issue was addressed more systematically in UNSCRs (from UNSCR 2270/2016). ${ }^{58}$ This process of cross-citation shows how UNSC permanent member states, like the United States, the United Kingdom or France, who place a lot of attention on the work of the FATF, can leverage the work of PoEs to raise the relevance of certain issues related to sanctions implementation, CFT or CPF in the global international security agenda; and how they can use the UNSC and its complex institutional architecture to commend FATF recommendations at multiple levels.

PoEs have played another important role by increasing the frequency of the monitoring and evaluation of national financial sanctions adopted by the UNSC. PoEs have sometimes gone beyond the FATF, which has a relatively thorough monitoring mandate involving eighteen-months of mutual evaluations, but at distant intervals - every five years or so. In contrast, PoEs conduct all-year-long, more or less independent investigations of any UNSC sanctions breaches reported by states, and issue up to two reports per year. Through their monitoring activities, the FATF and the PoEs participate in strengthening the expert belief that new 'targeted' sanctions always need to be added to past rounds of sanctions, according to a logic of a continuous progress in the detection of new

${ }^{54}$ UNSC, 'Letter Dated 12 May 2010 from the Panel of Experts Established Pursuant to Resolution 1874 (2009) Addressed to the President of the Security Council' (5 November 2010) UN Doc S/2010/571.

55 FATF, 'Typologies Report on Proliferation Financing'.

56 See UNSC Res 1803.

57 UNSC, 'Letter Dated 23 February 2015 from the Panel of Experts Established Pursuant to Resolution 1874 (2009) addressed to the President of the Security Council' (23 February 2015) UN Doc S/2015/131.

58 UNSC Res 2270 (2 March 2016) UN Doc S/RES/2270. 
types of practices and actors associated with illicit finance and sanctions violations. Whereas new measures are usually only added to an existing sanctions regime in response to actions that threatened international security and/or constitute a serious breach of the existing sanctions regime, PoE reports are routinely suggesting new targets to existing sanctions, based on the discovery of new methods or actors of sanctions evasion. With the precise enumeration of verified violation cases by PoEs, and the submission of their documentation to the scrutiny of the UNSC and its Sanctions Committees, the PoEs diffuse the view that new sanctions designations shall always improve the system of 'targetedness' and perfect the sanctions regimes already in place. Typical demands in PoE reports on the DPRK, for instance, are to close down new shell companies and new circuits of exchange (from cash economies to hawalas or networks exchanging digital currencies), which are created by proliferators in response to past rounds of targeted sanctions. PoEs not only seek to verify the validity of leaked intelligence and public information on new sanctions evasion techniques, but also lobby the UNSC member states to pass new rounds of sanctions meant to close the observed loopholes. Whether such an accumulation of targets leads to the progressive comprehensivization of sanctions or whether they can remain targeted in scope and discriminatory in nature is the question that we assess in Section 9.4.

Some examples illustrate how PoEs have encouraged states to go beyond the explicit requirements of UNSCRs and leave the ethos of diplomatic prudence in favour of a more expert-based justification for independent monitoring and forceful implementation of all of the UNSCRs' obligations and recommendations by UN member states. For instance, the UNSC decided in 2013 that member states shall prevent transfer of bulk cash through/to/from their territories if it 'could contribute to the DPRK's nuclear or ballistic missile programmes, or other activities prohibited by resolutions' (2094/2013 para. 11, emphasis added; UNSCR 2270 subjected gold transports to the same measures). ${ }^{59}$ The term 'could' is ambiguous and may invite very broad interpretations, but, if interpreted along a logic of targetedness, the measures should refer to cases with a credible risk that the gold/cash is being used for prohibited purposes. However, the wording suggests a broader interpretation, recommending that smuggled bulk cash or gold by DPRK nationals should

59 UNSC Res 2094 (7 March 2013) UN Doc S/RES/2094, para. 11. 
be frozen and that member states 'ensure that [frozen gold/cash amounts] cannot be used for prohibited activities or evasion of sanctions before releasing them' (S/2017/150, para. 253). ${ }^{60}$ Ensuring that assets cannot be used for prohibited tasks is a higher threshold pertaining to an eventual future that goes beyond the threshold of a credible risk that was more likely implied by the UNSCR.

To add another example, in UNSCR $2321,{ }^{61}$ the UNSC decided that 'all States shall take steps to limit the number of bank accounts to one per DPRK diplomatic mission and consular post, and one per accredited DPRK diplomat and consular officer, at banks in their territory'. The PoE repeatedly asked member states to go beyond these measures; in the following year, it passed the recommendation that member states 'must ensure that additional accounts are not established in the names of family members' (S/2017/742 recommendation C 5). ${ }^{62}$ Yet another year later, the $\mathrm{PoE}$ also recommended that member states apply the restrictions to all embassy personnel, ${ }^{63}$ as opposed to only the 'accredited DPRK diplomat and consular officers' mentioned in the UNSCR. ${ }^{64}$ A year later, the PoE recommended that states provide banks with a list of names of all family members of DPRK diplomats, to ensure that diplomats cannot open bank accounts in their names ${ }^{65}$ and that only one bank within each country be allowed to hold accounts of DPRK diplomats. ${ }^{66}$ Furthermore, the PoE recommended that 'Member States advise their financial

${ }^{60}$ PoE reports gave extensive evidence of sanctions evasions through the smuggling of cash and gold and that the PoE should thus feel a responsibility to propose counter-measures; likewise, the same report containing those recommendations stated that such contraband is frozen only exceptionally by states anyways; see UNSC, 'Letter Dated 17 February 2017 from the Panel of Experts Established Pursuant to Resolution 1874 (2009) Addressed to the President of the Security Council' (27 February 2017) UN Doc S/2017/150.

61 UNSC Res 2321 (30 November 2016) UN Doc S/RES/2321, para. 16.

${ }^{62}$ UNSC, 'Letter Dated 28 August 2017 from the Panel of Experts Established Pursuant to Resolution 1874 (2009) Addressed to the President of the Security Council' (5 September 2017) UN Doc S/2017/742.

63 UNSC, 'Letter Dated 1 March 2018 from the Panel of Experts Established Pursuant to Resolution 1874 (2009) Addressed to the President of the Security Council' (5 March 2018) UN Doc. S/2018/171, para. 210, recommendation 3.

${ }^{64}$ Ibid.

${ }^{65}$ UNSC, 'Letter Dated 21 February 2019 from the Panel of Experts Established Pursuant to Resolution 1874 (2009) Addressed to the President of the Security Council' (5 March 2019) UN Doc S/2019/171, para. 161.

${ }^{66}$ UNSC, 'Letter Dated 21 February 2019 from the Panel of Experts', para. 162. 
institutions not to open accounts for diplomats of the Democratic People's Republic of Korea who are not accredited to their country,, 67 based on the finding that North Korean embassies have served as traditional conduits of illicit financing. Still, if DPRK diplomats are prohibited, per UNSCRs, from holding more than one bank account, it lies in the discretion of the UNSC and its Sanctions Committee to designate any third-party individual assisting in the violation of this rule and there is, as of now, no UNSCR demanding that banks target family members of diplomats or that diplomats should not be allowed to choose a bank of their preference. The PoE thus recommends states to prevent sanctions evasions by recommending additional sanctioning measures that are not asked for by the UNSC. This is the very logic of illicit finance expertise that PoE members have endorsed.

A last example shows how private financial actors, too, can respond to the recommendations of the PoEs. In its 2017 report, the PoE on DPRK sanctions remarked that the Society for Worldwide Interbank Financial Telecommunication (SWIFT) maintained in its system North Korean banks that were designated for special attention by the UNSC. $^{68}$ As SWIFT is (only) the messenger between banks exchanging value through its system, and to the extent that banks are supposed to conduct the risk analysis related to specific payments (depending on a range of criteria), SWIFT's decision to keep these banks in its system may not have appeared a case of violation of the new UNSCR to its managers. Indeed, SWIFT provides the infrastructure that allows money to flow between accounts, and it leaves to those using that messaging infrastructure and ordering the money movements (e.g. banks sending messages through SWIFT) the responsibility to comply with the rules of UNSC, EU and US sanctions, and any other local systems of sanctions that may apply. This view of SWIFT's neutrality, however, was strongly challenged in the run-up to the Iran nuclear deal, when the P3 repeatedly asked SWIFT to disconnect some Iranian banks from its system between 2012 and 2015, and yet again after the USA left the Joint Comprehensive Plan of Action (JCPOA) after 2018. After the publication of this 2017 DPRK PoE report, SWIFT cut off the last North Korean banks from its messaging networks, thus cutting the whole North Korean formal financial

67 Ibid., para. 163.

68 UNSC, 'Letter Dated 28 August 2017 from the Panel of Experts'. 
system from the global network. ${ }^{69}$ In so doing, the Belgian-based financial organization implemented what looks like comprehensive rather than targeted sanctions against North Korea's financial system. It may have responded to the pressure due to the publication of the PoE report, or it may also have been retaliating due to the fact that the DPRK had manipulated its system by hacking the financial software that SWIFT sells to banks in order to initiate transfers of funds from one bank to another. In fact, in the last five years, it is estimated that the DPRK made more than US $\$ 1$ billion in this way, ${ }^{70}$ a huge sum compared to the income that the DPRK regime generated over the same period from arms sale in certain African countries, like Namibia or Ethiopia. ${ }^{71}$ These hacks may have convinced SWIFT that it needed the protection of the long arm of US judicial authorities to chase the hackers, bring them to justice and thus obtain a deterrent against other hacks in order to re-establish its credibility in the market of financial data management equipment. ${ }^{72}$ Whatever the reason, the publication of the PoE report was likely factored into its calculation

69 T. Bergin, 'SWIFT Messaging System Cuts Off Remaining North Korean Banks', Reuters (14 March 2017), www.reuters.com/article/us-northkorea-banks/swift-messagingsystem-cuts-off-remaining-north-korean-banks-idUSKBN16N2SZ.

70 Bloomberg, 'U.S. Sanctions North Korean Hackers for Swift Hack, Wannacry and Other Cyberattacks that Fund Its Weapons Programs', Japan Times (14 September 2019), www .japantimes.co.jp/news/2019/09/14/asia-pacific/u-s-sanctions-north-korean-hackersswift-hack-wannacry-cyberattacks-fund-weapons-programs/\#.XibZ1L97nq1.

${ }^{71}$ Notorious victims include the Bangladesh Bank, whose money (to the amount of US\$80 million) held in accounts at the New York Fed, was ordered in 2015 and 2016 to be transferred to the benefit of DPRK-controlled entities elsewhere (see FireEye, 'North Korean Hackers Used Swift Network to Steal More Than $\$ 100 \mathrm{~m}$ - Fireeye' Finextra (5 October 2018), www.finextra.com/newsarticle/32742/north-korean-hackers-used-swiftnetwork-to-steal-more-than-100m-fireeye). The fake money orders sent through SWIFT were impossible to distinguish from real money orders, which exposed vulnerabilities in the global SWIFT messaging system prior to the release of the $2017 \mathrm{PoE}$ report. See also S. Pham, 'North Korea Still Making Millions from Small Arms Exports' CNN (14 September 2017), https://money.cnn.com/2017/09/14/news/north-korea-smallarms-trade/index.html.

72 The US judicial authorities are the only ones with such sweeping powers thanks to the International Emergency Economic Powers Act, which lets them indict persons for comparably small offenses like giving a conference on Blockchain technology in the DPRK as an attempt to 'conspire' to violate the Act (See J. Brett, 'Internet Man of Mystery Virgil Griffith Indicted for Crypto Trip to North Korea', Forbes (11 January 2020), www.forbes.com/sites/jasonbrett/2020/01/11/internet-man-of-mystery-virgil-grif fith-indicted-for-crypto-trip-to-north-korea/\#2514738d18b0). 
when SWIFT decided to cut off the whole financial system of the DPRK regime from its messaging system.

It is understandable that PoEs would come up with strict interpretations of sanctions implementation, given that they are supposed to conduct monitoring and see themselves confronted with numerous violations. What matters in our context, however, is that the PoE recommends to member states that they take a maximalist interpretation of measures in UNSCRs that is mutually reinforcing with FATF recommendations and the comprehensive sanctions favoured by the USA in its campaign for 'maximum pressure' against states like Iran and the DPRK. It is worth emphasizing that the PoEs also formulate recommendations to the UNSC Sanctions Committees, which the UNSC Committees then discuss and vote upon. And even if Sanctions Committees do not act upon these recommendations, today, public and private authorities use the biannual PoE reports as interpretation guidelines for UNSCRs. As a consequence, PoE reports have shaped the expectations of the financial industry and their willingness to take risks, as each exchange in goods or financial transaction carries a remaining risk of inadvertently violating sanctions, should one, for instance, fall victim to deception or incomplete information. Just like the FATF, PoEs have continuously stressed that both private and public actors must be made aware of the importance of adopting a 'risk-based culture' ${ }^{73}$ But this call for a 'risk-based culture' can be interpreted very differently: either that you should accept that every decision comes with the risk of making the wrong decision, and that risks are part of life; or that you should take no risk of making a mistake by authorizing suspicious payments, especially when the penalty for making the wrong decision is too high. Clearly, the latter became the dominant interpretation, and this extension of the domain of what can be considered a 'risky activity' plays a role in the comprehensivization of sanctions, so we argue.

73 UNSC, 'Letter Dated 1 March 2018 from the Panel of Experts', para. 210 (recommendation 2): 'The Panel recommends that Member States, as part of their implementation of the financial provisions of the resolutions, ensure that their financial institutions implement a risk-based approach to identifying sanctions violations in their "know-yourcustomer" and compliance programmes ... To that end, Member States should provide their financial institutions with more detailed and regular information on sanctions evasion risks.' 


\subsection{The External Dynamics in the Comprehensivization of Sanctions: Legal Entanglements between Multilateral and Domestic Sanctions}

If the institutional innovations of the 2000s may give the impression of a general, sudden and unbeatable adoption of the targeted sanctions paradigm, and a stark contrast to the comprehensive sanctions against Iraq, some other trends already highlighted point to the entanglements between targeted and comprehensive logics as well as multilateral and unilateral sanctions regimes. One reason for this is that targeted sanctions were embedded in a broader decentralized network of comprehensive domestic prohibitions on any type of trade with certain countries under UNSC sanctions, especially Iran. We have already identified various facilitating dynamics in the entanglement of targeted and comprehensive logics at the level of the UNSC, which were most prevalent in the case of the DPRK, where the 'maximum pressure' campaign has been steered by the UNSC itself.

However, in cases like Iran, the UNSCRs only served to give a legal basis for sanctions that were otherwise mostly adopted in a unilateral manner, supposedly to 'complement' 'soft' UNSCRs that only 'called upon' states to adopt certain financial restrictions. In this case, the decentralization of targeting practices at the level of the $\mathrm{P} 3$, and the 'deputization' of sanctions implementation to Western-led global banks in charge of enforcing financial sanctions, as well as the inherent tendency of lists to grow ${ }^{74}$ under the proactive efforts of private sector vendors of sanctions lists, were much more influential processes explaining the comprehensivization of UNSC sanctions than efforts by PoEs and other international organizations like FATF. In what follows, we focus on a key driver of the entanglement between comprehensive (domestic) and targeted (UN-based multilateral) logics: a change in the notion of risk that was particularly fostered by US regulators.

While this section further works out the role of the USA as a key actor in fostering this entanglement, it also shows how 'the scope of relevant actors goes well beyond the governmental [or intergovernmental] sphere ${ }^{, 75}$ by pointing out the important role of private financial institutions. As the history of the last ten years of US judicial prosecution of financial crime shows, ${ }^{76}$

${ }^{74}$ De Goede and Sullivan, 'Introduction: The Politics of the List'.

${ }^{75}$ See Chapter 1.

76 G. Mallard and J. Sun, 'Viral Governance: How the US Unilateral Sanctions against Iran Changed the Rules of Financial Capitalism' American Journal of Sociology, under review. 
financial institutions have come to adopt a strategy of complete risk aversion with regards to sanctions under the influence of two important mechanisms: the adoption of comprehensive sanctions by the United States against Iran and the DPRK, and the extraterritorial effect of such unilateral sanctions on multinational companies - even outside the USA. These multinational companies were thus forced to choose between applying those sanctions to their global activities or facing the risk of exclusion from the US financial sector. Hence, when considering the risk of imposing comprehensive sanctions on civilian populations in Iran, global banks weighted another risk: that of being excluded from the leading world market and losing all of their US revenues. Furthermore, many of the UNSC sanctions against Iranian businesses involved prohibitions related to trade finance, and when they were framed by additional sanctions adopted by the USA and then by the EU (with the prohibition, after 2011, of oil import and export as well as of investment, insurance and credit related to the oil trade), it became easy for the US government to use the UNSCRs against Iran as a lever to police the activities of the world's leading banks in general, and the field of trade finance in particular.

For two decades, domestic US legislative acts slowly built up a comprehensive net that was supposed to catch any activity involving Iranian oil and the import/export of other commodities, with pretensions of legal extraterritoriality. At the domestic level, beginning in 1994 the USA passed the Nuclear Proliferation Prevention Act and Executive Order (EO) 12938 instituting a ban on US procurement from any person who, on or after 30 June 1994, knowingly and materially contributes, through the export of nuclear-related goods or technology, to the efforts of any individual, group or non-nuclear weapon state to acquire a nuclear explosive device or unsafeguarded special nuclear material. Through EO 12938, President Clinton declared a 'state of emergency' with respect to the proliferation of weapons of mass destruction. Then, the Export-Import Bank Act of 1996 instituted a ban on access to credit to any person who, after 23 September 1996, knowingly aided or abetted a non-nuclear weapon state to acquire a nuclear explosive device or unsafeguarded material, like Iran's enriched uranium not currently placed under IAEA safeguards. In the 2000s, a number of EOs complemented this legal basis, leading up to EO 13622, and EO 13645, which was adopted in 2013 and which prevented European and Japanese car companies present in Iran from continuing to sell cars and spare parts to the Iranian market. In parallel, the US Congress also passed a wide range of acts which banned trade with Iran 
and claimed extraterritorial competence: from the Helms-Burton Act to the 2011 Comprehensive Iran Sanctions, Accountability, and Divestment Act to the Iran Freedom and Counter-Proliferation Act and the Nuclear Iran Prevention Act of 2013 as well as various Defense Appropriation Acts in the early 2010s. During this period, reports abound of US pressure exerted directly by the US Treasury on foreign banks without going through national finance ministries, to directly push them 'to stop dealing with Iran'. 77

Taken together, these US 'emergency' measures with extraterritorial ambitions banned credit, guarantees or insurance in support of exports to Iranian sanctioned individuals; forbade US imports from sanctioned entities; and froze the assets of Iranian sanctioned entities within US jurisdiction even before a trial could be held. From 2008 until 2015, wholesale sectoral prohibitions (especially targeting Iran's financial sector), which had been opposed - and specifically vetoed - by the Russian and Chinese governments in the UNSC, were unilaterally added post hoc by EU and US governments in the form of domestic instruments. For private actors like global banks, applying only the targeted sanctions of the UNSCRs against Iran would thus have meant ignoring US and EU sanctions, and exposing themselves to the 'risk' of committing sanctions violations in the two largest economies of the world, even if the transactions concerned didn't take place in the USA or Europe.

Some banks originally contemplated such action, but they were convinced to change strategy and take maximal measures to avoid any kind of financial contact with individuals and entities targeted by the US Treasury - and not only with them, but also with entities that may be suspected of carrying a second or third degree of relationship with such targeted entities, as interviewees in Washington told us. In a few years, from 2005 to 2015, the US government levied fines against global banks that handled transactions to Iran and Sudan which were prohibited under US law (but not under UNSC resolutions or even EU law) if these transactions were denominated in US dollars. These fines amounted to billions of dollars, as in the case of the fine that BNP-Paribas had to pay to US authorities for clearing transactions in its New York branch related

77 S. Fayazmanesh, The United States and Iran: Sanctions, Wars and the Policy of Dual Containment (Routledge, 2008), p. 198; see also S. Fayazmanesh, 'The Politics of the US Economic Sanctions against Iran’ (2003) 35 Review of Radical Political Economics 221-40. 
to Iranian oil proceeds coming from or going to Iran and Iranian entities that were denominated in US dollars. ${ }^{78}$

Our interviewees, who worked as compliance officers in private financial institutions before the signing of the JCPOA, insisted that it was impossible to apply the logic of targeted sanctions to Iran during this period: for them, the potential benefits of admitting Iranian clients or carrying out transactions from/to Iran were not worth the intense vetting procedures that would have been required each time; furthermore, the remaining risk of unwittingly admitting prohibited transactions despite such vetting procedures was even less acceptable. While it is true that entities linked to either Iran's or now North Korea's nuclear programmes have taken many covert identities and used many masks to hide their links to these programmes, with this amount of suspicion in these cases, banks and their compliance departments that were asked by the UNSC to adopt 'vigilance' and its associated concepts of 'enhanced due diligence' in fact stopped calculating the risks associated with every transaction and rather engaged in wholesale practices of derisking. ${ }^{79}$

The signing of the JCPOA didn't change that situation, as it left in place many US domestic sanctions based on the US designation of many Iranian entities as linked to groups (like Hezbollah) that the US government designated as terrorists, which meant that global banks were still wary of too quickly changing their regulation with regard to Iran. After the JCPOA was signed, the logic of targetedness should have meant that, with the lifting of the comprehensive EU and US trade sanctions that targeted the oil trade and investment activities in Iran, the financial sanctions would have been lifted at the same time as sectoral restrictions. This is not what happened. The post-JCPOA situation in Iran suggests that sanctions against Iran followed the logic of comprehensive sanctions. ${ }^{80}$ According

${ }^{78}$ For instance, see Department of Justice, 'Standard Chartered Deferred Prosecution Agreement' (2012), www.justice.gov/opa/pr/standard-chartered-bank-agrees-forfeit-227-mil lion-illegal-transactions-iran-sudan-libya-and; OFAC (Office of Foreign Assets Control, U.S. Treasury Dept.), 'BNP Paribas Deferred Prosecution Agreement' (2014), www.treasury .gov/resource-center/sanctions/CivPen/Documents/20140630_bnp_settlement.pdf.

79 P.-E. Dupont, 'Compliance with Treaties in the Context of Nuclear Non-proliferation: Assessing Claims in the Case of Iran' (2013) 19 Journal of Conflict and Security Law 161-210; Mallard, Sabet and Sun, 'The Humanitarian Gap in the Global Sanctions Regime'; Department of Justice, 'Standard Chartered Deferred Prosecution Agreement'; OFAC (Office of Foreign Assets Control, U.S. Treasury Dept.), 'BNP Paribas Deferred Prosecution Agreement'.

80 P. Clawson, 'Sanctions as Punishment, Enforcement, and Prelude to Further Action' (1993) 7 Ethics \& International Affairs 17-37. 
to the logic of comprehensive sanctions (and, as previously illustrated in the case of sanctioned individuals whose names are likely to stay on the financial sector's blacklists forever, even if they have been delisted by the UNSC), once a country has been labelled as a 'cause of money laundering concern' by the organizations in charge of issuing such statements (e.g. the FATF, or the US Treasury and its Office of Foreign Assets Control (OFAC)), it becomes almost impossible for that country and its economy to be brought back into the community of global banks.

It is therefore not a surprise that, after the Iran nuclear deal of 2015, the first law that Iran contemplated was the so-called 'FATF bill' - heatedly debated in the Iranian Parliament - which required that Iranian banks adopt AML and CFT measures promoted by the FATF in order to convince the FATF to change its designation of Iran as a country of money-laundering concern. But even as this legislative effort was pursued in Iran, it was clear that the efforts would hardly bring a change in the FATF's assessment of Iran's political economy, not to speak of OFAC's assessment, and that the reinclusion of Iranian financial institutions (after years of exclusion) was next to impossible, even if the JCPOA explicitly called on European private companies and banks to work towards Iran's economic recovery by investing massively in its oil sector.

This path dependency illustrated the comprehensive logic of CPF sanctions. It was reinforced, in the specific case of Iran, by the decision made by the US president to pull out of the JCPOA, despite the fact that UNSCR 2231 gives it the force of law. After 2018, banks faced for the first time a stark option: either follow the logic of targeted sanction, by applying only the prohibitions contained in the UNSCRs, or to follow US domestic changes in their worldwide activities. Their over-cautious behaviour, and their refusal to touch any oil-financing schemes in Iran clearly shows which direction they have chosen to follow since 2018. It is unlikely that, even with the change in the US administration, the contradictions between US and multilateral sanctions will be eliminated and that the logic of targetedness will be strictly followed in the counter-proliferation field.

\subsection{Conclusion}

Today, many international organizations, including the World Bank ${ }^{81}$ or the International Monetary Fund (IMF), have issued warnings after

${ }^{81}$ World Bank, 'De-risking in the Financial Sector' (7 October 2016) www.worldbank.org/ en/topic/financialsector/brief/de-risking-in-the-financial-sector. 
realizing that global banks and other financial actors have massively pulled out of sanctioned jurisdictions as they applied sanctions in a comprehensive manner rather than by implementing narrow sanctions exclusively targeting the culprits responsible for a country's wrong policy course. ${ }^{82}$ International organizations such as the IMF or the World Bank see such cases of overcompliance as illegitimate in an age when comprehensive sanctions are no longer deemed appropriate under new norms of 'civilized' state conduct. Still, global banks and other financial actors are not solely responsible for that 'comprehensivization' of sanctions: the movement is spurred by the entanglements between targeted and comprehensive logics, especially in the field of counter-proliferation sanctions. These legal entanglements have been patiently weaved together by a proliferation of other international organizations, including the FATF and the Panel of Experts created by the UNSC Sanctions Committees, particularly those verifying the implementation of sanctions against Iran and the DPRK. Together, these organizations have participated in the creation of a fiction which implies that 'targetedness' would necessarily rhyme with 'narrowness', when in fact 'targetedness' is not necessarily incompatible with 'comprehensiveness': if the list of 'targets' is gradually or suddenly extended to become all-encompassing, then targeted sanctions could be both targeted and comprehensive in principle.

If we observe a general trend towards the 'comprehensivization' of socalled 'targeted' sanctions, then why do all these institutions still claim to design, monitor and enforce 'targeted' sanctions? In fact, we claim that the logic of targetedness is no longer an empirical fact, or even a policy goal, which would be shared by UNSC member states, but it has become a functional assumption that is necessary for the system to continue operating. By implicitly accepting that states are compartmentalized and cannot be assumed to be in full control of their many state agencies nor private actors, all the organizations which claim that the system operates under the logic of targetedness enact a useful charade or 'fiction ${ }^{83}$ that allows all governments to distance themselves from the entities suspected of breaching US, EU or UNSC sanctions: if parts of a government are blamed by a PoE or by a foreign government branch (the US Department of Justice or OFAC in particular) for sanctions violation, the central authorities can always claim that such entities couldn't have

${ }^{82}$ Mallard, Sabet and Sun, 'The Humanitarian Gap in the Global Sanctions Regime'.

${ }^{83}$ A. Riles, Collateral Knowledge: Legal Reasoning in the Global Financial Markets (University of Chicago Press, 2011). 
acted on behalf of the state, and that they weren't responsible for such failings. Here, the logic of 'targetedness' - with its separation between states and individual perpetrators - protects member states and thus makes their consent to sanctions, including sanction enforcement and monitoring, more likely.

We not only see this protective mechanism functioning in the cases of US sanctions enforcement against Europe's major banks (from BNPParibas to HSBC), in which European governments have largely turned their eyes away from the settlements, but also during PoE investigations, as in the case of the DPRK. It is standard practice for most UNSC PoEs that PoE members would never publish information in their report without first giving the monitored state (for instance, Russia, Vietnam or Ethiopia) the chance to either deny and disprove accusations or work to solve problems. Thus, where PoEs uncover sanctions violations in a given country, they tend not to link violations to governments as a whole but only to specific actors or entities within a country (even if the actors in question are state agencies). For instance, as reported by the DPRK PoE in 2018 in the case of Russia, Russian companies that forged joint ventures with DPRK state companies in violation of UNSC sanctions needed to be investigated, and the PoE members could gain Russia's support for their investigations by allowing the government to claim that such entities had violated the government's will if they did create such joint ventures. By operating under the assumption that states are not complicit in sanctions violations before having been alerted of the existence of these violations by PoEs or by OFAC investigations, multilateral and domestic investigatory bodies give them the benefit of the doubt, and strengthen the belief that a few bad apples within the state may have covered up such illegal behaviours, or that miscommunication problems within complex administrations may have prevented such information from surfacing. Investigatory bodies in the field of sanctions enforcement normally use this assumption as a public script when interacting with states or private actors, even where they may find it hard to believe it themselves.

In this chapter, we have also identified several reasons why UNSC member states (especially the P3) have preferred to entangle a comprehensive set of interventions with a targeted sanction regime, rather than imposing comprehensive sanctions in the first place: first, the lack of legitimacy of blatantly comprehensive regimes, at least since the Iraq case; second, the fact that within the UNSC, Russia and China, and sometimes European states, would not agree to adopt comprehensive 
sanctions against a UN member state, as they are rather critical of sanctions; and third, because the fiction that enforcement actions against sanctions violations should also be targeted helps protect UN member states from being accused of having been complicit in sanction violations, which means, in turn, that sanctions violators are likely to opt more often for cooperation rather than conflict when accused of misdeeds.

Sanctions experts and policy-makers who pursue an interest in upholding peace and the rule of international law through sanctions (rather than war) as well as a concern for human rights may be convinced of the necessity to fight the trend towards comprehensivization, as it risks creating the same human rights disasters in Iran, Venezuela or Syria today that were witnessed in Iraq in the 1990s. They may see this trend as a distortion of their original intent and a misuse of the instruments of algorithmic governance that they collectively created. However, we argue that the financialization of the sanctions regimes bore in its premises an inherent dynamic towards comprehensivization, which could only reveal itself after the first wave of sanctions were adopted and implemented, when contradictions between comprehensive domestic sanctions regimes and narrower multilateral sanctions regimes were partially solved to the benefit of the former, with one reason being the private financial sector's changing notion of 'risk'.

To that extent, we believe that the concept of legal entanglement, which places the focus of socio-legal scholars and international organizations specialists at the intersection between these domestic, transnational and multilateral dynamics, is particularly useful to social scientists who are dissatisfied with the old notion of 'international regime', even reworked through the use of the updated notion of 'regime complexity', as well as to policy-makers who are interested in reconciling sanctions with a concern with human rights. Its use suggests that although efforts to arrive at a more coherent system of rules are welcome, they rarely achieve complete success, and that regimes traversed by a plurality of contradictory rules are not inherently unstable: to the contrary, such legal entanglements can be quite stable over time. 